Хренов Н.А.

\title{
Проект семиотики кино спустя несколько десятилетий: интерпретация теоретического наследия С. М. Эйзенштейна Вяч. Вс. Ивановым
}

Аннотация: Статья посвящена предпринятому академиком Вяч. Вс. Ивановым, юбилей которого отмечался в этом году, семиотическому истолкованию теоретического наследия кинорежсиссера С. М. Эйзенштейна, предвосхитившего столь популярную с 6о-х годов структуралистскую методологию. Научные интересы Вяч. Вс. Иванова чрезвычайно широки. В данной статье затрагивается только его интерес к кино и, в частности, к творческому наследию кинорежиссера С. М. Эйзенштейна. Это наследие привлекло внимание Вяч. Вс Иванова потому, что в нем академик обнаружил движение в сторону понимания кино как языка или, еще точнее, знаковой системы. Вяч. Вс. не мог не обратить на это внимание, поскольку становление семиотической методологии в России связано именно с его именем. Естественно, что он не мог не осмыслить и предысторию семиотики. Такая предыстория в сфере кино связана с именем С. М. Эйзенштейна. Пытаясь понять значение исследования Вяч. Вс., посвященного эстетике C. М. Эйзенштейна, автор также касается применения семиотической методологии к кино как знаковой системы вообще В связи с этим в статье воспроизводится атмосфера увлечения семиотикой отечественными теоретиками кино. Однако спустя десятилетия интерес к структурализму и семиотике начал угасать. Это происходило по мере появления в гуманитарной науке подходов, связанных с постструктурализмом и постмодернизмом. Некоторые теоретики начали активно ниспровергать семиотические подходы, призывая к философскому и, в частности, феноменологическому подходу в изучении кино. Такие подходы возможны и конструктивны, но они однако не упраздняют и семиотический подход. Автор статьи показывает, что такие попытки ниспровержения семиотического проекта кино оказываются преждевременными и поверхностными. Чтобы это осознать, необходимо вчитываться в работы Вяч. Вс. Иванова, посвященные кино. В них философский подход подразумевается. Об этом, в частности, свидетельствует книга Вяч. Вс. «Эстетика Эйзенштейна». Расшифровывая смысл названия книги Вяч. Вс. Иванова, автор показывает, что идея семиотики возникла уже на первоначальном этапе становления эстетики как философской науки.

Review: The article is devoted to the semiotic interpretation of the theoretic heritage of a film director Sergey Eizenshtein by Vyacheslav Ivanov whose jubilee was celebrated this year. Sergey Eizenshtein foresaw the structural methodology that became so popular after the 6os. Vyacheslav Inavov has a wide range of academic interests. The present article is devoted only to his interest towards cinematograph, in particular, the theoretic heritage of a film director Sergey Eizenshtein. Vyacheslav Ivanov is interested in Eizenshtein because Vyacheslav Ivanov believes that Eizenshtein tended to see cinema as a language or, more specifically, a sign system. Vyacheslav Ivanov couldn't have left it without attention because the formation of semiotic methodology is closely related to Eizenshtein in Russia. So it is quite natural that Vyacheslav Ivanov wanted to interpret the pre-history of semiotics, too. In cinematograph such pre-history is directly related to Sergey Eizenshtein. Trying to clarity the significance of Vyacheslav Ivanov's research of Sergey Eizenshtein's esthetics, the author of the present article also touches upon applying semiotic methodology to cinematograph as a sign system in general. For this purpose, the author describes the atmosphere of those times when Russian theorists of cinematograph were interested in semiotics. However, interest towards structuralism and semiotics started to fade away decades later when new approaches related to pot-structuralism and post-modernism were introduced by the humanities. Some theorists started to speak against semiotic approaches and suggested to apply philosophical and, in particular, phenomenological approach to studying cinematographic art. These approaches are appropriate and efficient, however, they do not replace the semiotic approach. The author of the article shows that such attempts to refuse from the semiotic approach to cinematograph were too early and superficial. Vyacheslav Ivanov's works on cinematograph are a great source that proves the efficiency of the philosophical approach. In particular, Vyacheslav Ivanov's book 'Eizenshtein's Esthetics' is de- 
voted to this topic. Interpreting the meaning of the title, the author of the present article shows that the concept of semiotics was already created at the initial stage of the development of esthetics as a branch of philosophy.

Ключевъе слова: Семиотика, лингвистика, структурализм, феноменология, эстетика, язык кино, знаковая система, формальная школа, культура грамматики, культура текста.

Keywords: Semiotics, linguistics, structuralism, phenomenology, esthetics, language, cinema, sign system, formal school, culture of grammar, culture of text.

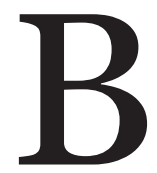
сентябре 2014 года прошла научная конференция с международным участием «Семиотика - психология - культурология: новые водоразделы и перспективы взаимодействия». Она была организована Русской антропологической школой Российского государственного гуманитарного университета, Новым институтом культурологии, Институтом мировой культуры Московского государственного университета им. М. В. Ломоносова, Эйзенштейновским центром исследования культур и приурочена к 85-летию академика Вяч. Вс. Иванова.

Для каждого гуманитария, в том числе, для автора, это имя многое значит. Научные интересы Вячеслава Всеволодовича чрезвычайно широки. Но в данной статье мы затронем лишь его интерес к кино и, в частности, к теоретическому наследию С. М. Эйзенштейна. Это наследие привлекло внимание В. В. Иванова потому, что в нем со всей очевидностью проявилось движение в сторону понимания кино как языка или, еще точнее, знаковой системы. В. В. Иванов не мог не обратить на это внимание, поскольку становление семиотических идей в России связано именно с его именем. Естественно, что он не мог не осмыслить и предысторию семиотики. Такая предыстория в сфере кино связана с именем С. Эйзенштейна. В свое время книга В. В. Иванова о С. Эйзенштейне позволила понять идеи С. Эйзенштейна, в том числе, и теоретикам кино. Идеи, высказанные в этой книге, повлияли на интерес автора к теории и семиотике кино. Впрочем, повлияла не только данная книга, но и другие публикации В. В. Иванова, особенно те, что касаются кино (но даже если В. В. Иванов писал не о кино и не о С. Эйзенштейне, он постоянно касался и кино, и С. Эйзенштейна), а также его многочисленные выступления и доклады, которые автор слышал в 6о-е годы, когда был еще студентом Института кинематографии. Когда автор написал диплом- ную работу о структурном анализе фильма и оказался в трудной ситуации (ибо члены Государственной экзаменационной комиссии никогда не слышали о предмете моего исследования и не знали, как это оценивать), пришлось обращаться к В. В. Иванову и ходить в Лаврушинский переулок в дом писателей, где он жил в 60-е годы.

Конец 60-х - это время, когда структурализм и семиотика входили в моду, а все новое подвергалось критике, отрицанию со стороны чиновников, идеологов, консервативной и официальной части гуманитарного сообщества. Новым идеям грозила участь формальной школы, деятельность которой в конце 20х годов была искусственно прервана. Тем не менее, представители многих научных дисциплин разделяли этот интерес к новой методологии. Казалось, она поможет разрешить некоторые трудные проблемы и в искусствознании, и в киноведении, обещает перспективы. Она способствовала интересу к теории кино.

Позволим себе высказать несколько суждений не только по поводу конкретной книги В. В. Иванова о С. Эйзенштейне, а именно это и будет главным предметом данной статьи, но и о судьбе той методологии, даже той науки, которая в нашем сознании связывается с именем В. В. Иванова. Ведь и в самой книге о С. Эйзенштейне речь идет не только о С. Эйзенштейне, но вообще о приложении семиотической методологии как части общей методологии гуманитарных наук к кино. Так что от своего предмета уклоняться не приходится. Собственно, именно так выстраивается книга В. В. Иванова «Очерки по истории семиотики в СССР», вышедшая в 1976 году ${ }^{1}$. В ней естественно в основном говорится о С. Эйзенштейне. Но все же она выстраивается как история семиотики.

Хотя в намерения автора входит говорить о книге В. В. Иванова более конкретно

${ }^{1}$ Иванов В. Очерки по истории семиотики в СССР. М., 1976 
и более подробно, все же невозможно пройти мимо той критики, которая в последнее время высказывается по поводу того проекта семиотического исследования кино, у истоков которого в нашей стране стоит В. В. Иванов. По-моему, это не менее важно, чем обращение к высказываемым в книге конкретным положениям.

В России острые дискуссии по поводу структурализма уже давно не ведутся. Мода угасла. На смену структурализму пришел сначала постструктурализм, затем постмодернизм. Постепенно в поле внимания оказались другие идеи и другие взгляды. Выяснялось, что структура совсем не является закрытой, как это представлялось структуралистам. Она открыта и предполагает множество интерпретаций. Например, Ж. Деррида утверждает, что не существует тех отношений между означающим и означаемым, которые сформулированы структуралистами. По его мнению, всякий знак является знаком знака, следом следа, означающее означающего, звено в бесконечной цепи отсылок, никогда не достигающего означаемого ${ }^{2}$. Что касается структурализма, то для Ж. Дерриды это тотальное наступление «на живое многообразие и сведение его к мертвым структурам» ${ }^{3}$. Даже некоторые ревностные последователи структурализма в этой методологии успели разочароваться и начали выступать с его критикой. Поэтому возвращаясь к книге В. В. Иванова о С. Эйзенштейне, в которой Сергей Михайлович представлен предтечей киносемиотики ${ }^{4}$, нельзя не учитывать радикально изменившуюся ситуацию, новый дух времени.

Впрочем, сам Вячеслав Всеволодович не исключает критики. Он готов предъявить науке XX века серьезный счет. Невозможно в связи с этим не процитировать одно место из другой его работы «Очерки по предыстории и истории семиотики», в которой ученый дает оценку переживаемому в последние десятилетия застою в гуманитарных науках. Признавая успехи науки, он, однако, пишет: несмотря на то, что накоплен колоссальный экспериментальный материал, наука о человеке бедна новыми идеями и обобщениями.

\footnotetext{
${ }^{2}$ Автономова Н. Деррида и грамматология // Деррида Ж. О грамматологии. М., 200о., с. 33;

${ }^{3}$ Автономова Н. Указ. соч., с. 54;

${ }^{4}$ Иванов В. Указ. соч., с. 56;
}

В данном случае В. В. Иванов говорит об этом в связи с психологией, но эту оценку распространяет, в том числе, и на философию, религию, искусство. По его мнению, наше время несопоставимо с тем ренессансом, который имел место в первые десятилетия XX века («Везде или почти везде мы продолжаем жить отблесками того взрыва новых идей и замыслов, которыми была охвачена творческая Европа (включая и Россию) на заре века» 5. Так, если иметь в виду искусство, то после Сезанна и открытой африканской скульптуры, за которыми последовали кубистические эксперименты Пикассо и Брака, мало что возникло нового. Нельзя утверждать, что эта логика к кино неприменима.

Тут кое-что следовало бы уточнить. Конечно, скажем, формализм как исходная точка в движении к семиотике как раз и выражает то, что В. В. Иванов подразумевает под отблесками взрыва новых идей и замыслов. Но разве снова возникший в эпоху оттепели, т.е. в середине века интерес к формалистам не свидетельствовал о новом подъеме в науке? При этом нельзя утверждать, что в это время формализм лишь вспоминали. Его творчески развивали, продолжали, чему способствовали такие ученые, как К. Леви-Строс. И к этому подъему гуманитарных наук в 6о-е годы кино как раз и имело отношение.

Касаясь вопроса о приложении методов семиотики к кино, нельзя пройти мимо той критики этого приложения, которая прозвучала из уст М. Ямпольского. В своей книге «Язык-тело-случай: кинематограф и поиски смысла» он описывает свой выход, как он выражается, за рамки «семиотической догмы». По его мнению, ориентация семиотического анализа кино на лингвистику, что, собственно, и дает основание говорить о знаковой природе кино, совсем не позволяет разрешить многие вопросы. Кино вовсе не является знаковой системой. Он несколько раз употребляет словосочетание «догматический структурализм», словно речь идет о марксизме, ленинизме или большевизме в современном их понимании. И вот окончательный приговор М. Ямпольского: «Семиотика задохнулась

${ }_{5}^{5}$ Иванов В. Очерки по предыстории истории семиотики // Иванов В. Избранные труды по семиотике и истории культуры., т. 1. Знаковые системы. Кино. Поэтика. М., Языки русской культуры., М., 1998., с. 749; 
от собственного сциентизма и отсутствия философского фундамента» ${ }^{6}$.

Таким образом, М. Ямпольский словно повторил расстановку сил, которая в истории семиотики уже имела место. Иначе говоря, он повторил позицию М. Бахтина по отношению к предшественникам семиотики - формалистам, для которых характерна ориентация на лингвистику. Как выражается Ю. Кристева, М. Бахтин «на руинах формалистической поэтики» ${ }^{7}$ создает собственную концепцию, ставя знаковую систему в зависимость от положения субъекта в истории, а это положение все время изменяется, что обязывает изменяться и знакам. Вот как комментирует этот выход М. Бахтина из формализма его глубокий интерпретатор Ю. Кристева. «...В результате значение начинает рассматриваться, - пишет она - как конкретное функционирование, пребывающее в процессе постоянной трансформации в зависимости от положения субъекта в истории, т.е. как высказывание - процесс, конституирующее некий конкретный смысл (и в то же время некую идеологию) в связи с тем конкретным отношением, которое субъект поддерживает с собственным дискурсом (отличным от языка) здесь и теперь» 8 .

Такое же разочарование в семиотическом истолковании искусства и, в частности, кино высказывает в своей книге «Киноведение как наука» В. Соколов. В этой книге опубликована статья «Несколько предварительных замечаний к разделу «Структурно- семиотическое киноведение». Она начинается с четкого формулирования краха структуралистского проекта в кино. По крайней мере, в российском киноведении. В ней также названы причины этого краха. Автор пишет: «Структурно-семиотическое киноведение у нас не привилось. Две - три отечественные монографии, десяток - другой статей и ряд зарубежных исследований, переведенных на русский язык. Все это не оставило сколько - нибудь заметного следа ни в советской (прошлой), ни в российской (нынешней) науке о кинематографе» 9. В частности, в качестве при-

\footnotetext{
$\overline{6}$ Ямпольский М. Язык - тело - случай: Кинематограф и поиски смысла. М., 2004., с. 10;

7 Автономова Н. Открытая структура: Якобсон Бахтин - Лотман - Гаспаров. М., 2009., с. 122;

${ }^{8}$ Кристева Ю. Избранные труды: Разрушение поэтики., М., 2004., с. 11;

9 Соколов В. Киноведение как наука. М., 2010., с. 58;
}

чин краха семиотики В. Соколов указывает на идеологические установки, а также на несовершенную систему образования кинематографистов, в которой семиотика не нашла места. Правда, этот момент характеризует лишь систему воспитания кинематографистов, но не семиотику.

Констатируя провал семиотического проекта в кино, В. Соколов все же отдает должное тем направлениям в гуманитарной науке, которые, действительно, ближе лингвистике. По его мнению, кино к ним не относится. Речь идет о филологии и литературной поэтике, но не о кино. Но, как это получается у В. Соколова, ныне семиотика и структурализм если и не вытеснены окончательно другими идеями постструктуралистской эпохи, то серьезно потеснены («Эпоха «бури и натиска» киносемиотики действительно завершена») ${ }^{10}$.

Трудно сказать, сформировался ли этот приговор семиотике под воздействием постмодернистов или цитируемые авторы пришли к этому выводу самостоятельно, но все-таки они буквально повторяют Ж. Дерриду, утверждающему, что и понятие, и слово «знак» необходимо устранить. «Ведь по самой своей сути «знак». - пишет он - всегда понимался и определялся как «знак чего-то», как означающее, отсылающее к определенному означаемому, как означающее, отличное от своего означаемого» ${ }^{11}$. В своей книге «О грамматологии» Ж. Деррида утверждает, что «идея знака принадлежит определенной исторической эпохе», а сегодня наступает новая эпоха и, следовательно, «пришла наконец пора «перейти к чему-то другому», избавиться от знака - как термина и как понятия» 12. Как формалисты, так и структуралисты вдохновлялись лингвистикой. Собственно, именно эта зависимость от лингвистики и обязывала многое в культуре рассматривать по аналогии со словом, т.е. знаком в его вербальной форме. Но Ж. Дерриду интересует то, что поддается осмыслению не с помощью лингвистики, а именно, жест, предшествующий слову. Так, посвятив театру жестокости специальную работу, он в ней пишет: «Глоссопойесис (это и не подражательный язык, но и не сотворение имен)

\footnotetext{
${ }^{10}$ Соколов В. Указ. соч., с. 58 ;

${ }^{11}$ Деррида Ж. Структура, знак и игра в дискурсе гуманитарных наук //Французская семиотика: От структурализма к постструктурализму. М., 2000., с. 410; ${ }_{12}$ Деррида Ж. О грамматологии. М., 2000., с. 129;
} 
подводит нас именно к той черте, где слово еще не родилось, когда говорение уже перестало быть простым криком, но еще не стало членораздельной речью, когда повторение и, стало быть, язык как таковой (требующий разделения понятия и звука, означаемого и означающего, пневматики и грамматики, предполагающий свободу перевода и традиции, изменчивость интерпретаций, различие между душой и телом, господином и рабом, Богом и человеком, автором и актером) оказываются почти невозможными» ${ }^{13}$. Что же из этого проистекает? А то, что лингвистическая или семиотическая проблема трансформируется в психологическую проблему. Именно поэтому Ж. Деррида проявляет интерес к психоанализу. Итак, поворот от семиотики к психологии. У. М. Ямпольского поворот - к философии.

В. Соколов связывает прогресс в гуманитарных науках с культурологией, которая в последние десятилетия претендовала на роль лидера. Но констатируя эту трансформацию, В. Соколов не учитывает того, что семиотика внесла ценные идеи в становление именно этой науки. Эти направления неправомерно противопоставлять. Стоит здесь хотя бы назвать работы Ю. Лотмана, в частности, его работу «О семиотическом механизме культуры» 14. Высказанная в этой работе Ю. Лотманом идея о существовании двух типов культуры - культуры текста и культуры грамматики - весьма плодотворная идея. Она, в частности, может объяснить и интерес в 60-е годы к семиотике, в которой снова активизируется и получает выражение тип культуры, который Ю. Лотман называет культурой грамматики. Отсюда и вновь возникающий интерес к построению поэтики.

Собственно, линия культуры, точкой отправления которой является модерн, т.е. эпоха Просвещения (я здесь использую терминологию Ю. Хабермаса) постоянно воспроизводит культуру грамматики. Не случайно идея семиотики становится актуальной в эпоху раннего модерна задолго до появления в 1916 году «Курса общей лингви-

\footnotetext{
${ }_{13}$ Деррида Ж. Театр жестокости и завершение представления //Французская семиотика: От структурализма к постструктурализму. М., 2000., с. 389;

${ }^{14}$ Лотман Ю. О семиотическом механизме культуры // Лотман Ю. Избранные статьи в 3-х т., т. 3., Таллинн., 1993., с. 326;
}

стики» $Ф$. де Соссюра, с которой, собственно, как это принято считать, и начинается интерес к семиотике. Культура грамматики появляется тогда, когда тот или иной народ в своей истории переживает радикальные пересмены. В связи с этим стоит согласиться с мыслью Ю. Кристевой о том, что в семиотическом дискурсе получил отражение «процесс того культурного переворота, который переживает в настоящее время наша цивилизация» ${ }^{15}$. Но в XX веке человечество именно такой переворот и переживает.

Однако дело обстоит сложнее. Интерес к семиотике, пытающейся в XX веке найти свое место в системе гуманитарных наук, может свидетельствовать не только о притязаниях самой новой науки, а о потребности культуры в этой науке. В этой связи нельзя не обратить внимание на другое суждение Ю. Кристевой, связанное с возможностью благодаря семиотике осознать в европейской культуре те комплексы, которые с помощью существовавших научных процедур скорее скрывались и подавлялись, нежели становились предметом рефлексии. Таким образом, семиотика отвечала потребности культуры в углубленном самопознании. «Это означает - пишет Ю. Кристева - что семиотика оказалась тем исходным пунктом, благодаря которому наука получила возможность вновь обратиться к таким знаковым практикам, которые официальная европейская культура долгое время утаивала и вытесняла, а общество, управляемое однозначными и линейными законами речи и обмена, объявляло иррациональными или опасными» ${ }^{16}$.

Что же это за практики, которые европейская культура вытесняла? Сама Ю. Кристева их не называет, но их можно обнаружить в работах Ж. Дерриды, который разводит лингвистику, с одной стороны, а вместе с ней и всю практику логоцентризма, и психоанализ, с другой. Именно в психоанализе, т.е. в том, что предшествует слову, знаку Ж. Деррида находит то, что позволяет преодолеть логоцентризм. «Наши притязания весьма скромны, - пишет Ж. Деррида найти в тексте Фрейда несколько открытых точек и, не претендуя на систематичность, выделить в психоанализе все то, что не вмещается в рамки логоцентризма, поскольку они ограничивают не только историю фи-

${ }_{15}^{15}$ Кристева Ю. Указ. соч., с. 53; 
лософии, но и становление «гуманитарных наук», включая известного толка лингвистику. Если прорыв, осуществленный Фрейдом, и вправду имеет историческое своеобразие, то причина отнюдь не в мирном сосуществовании с этой лингвистикой и не в теоретической ей сопричастности - по крайней мере, в том, что касается ее врожденного фонологизма» ${ }^{17}$.

Становление семиотики как науки тесно связано с происходящими в культуре изменениями и потребностью в уточнении того, что следует под культурой понимать. Эти дисциплины в своем развитии дополняют друг друга. Культурологический дискурс вовсе не вытесняется семиотическим дискурсом, как это получается у В. Соколова. Так что с мнением В. Соколова по поводу того, что культурологический подход как более новый и более совершенный вытесняет подход семиотический, согласиться невозможно. В этом отдаешь отчет, перечитывая книгу В. В Иванова, для которого функционирование знаковых систем предстает проблематикой культуры. Ведь его интересует то же, что интересует и Ж. Дерриду. В этом и состоит разгадка того, почему Вячеслав Всеволодович на протяжении всей своей жизни испытывает интерес к кино и, в частности, к практикам, вызванным к жизни С. Эйзенштейном с его тяготением к психоанализу. Не следует спешить соглашаться ни с В. Соколовым, ни с М. Ямпольским по поводу подведения черты под якобы неудавшимся семиотическим проектом и его применением в кино.

Представляется, что нормальная и конструктивная критики - составляющая научного процесса. Критика в науке играет позитивную роль. Критика семиотического проекта в России и, в частности, в его кинематографическом варианте тоже способна играть конструктивную роль. Так в истории было всегда. Разве Кант не подвергал критике всю предшествующую философию? Разве он вообще не создавал свои сочинения в жанре критики? Но история с наскоками в адрес семиотики кино в еще большей степени напоминает критику столь авторитетного в социологии функционализма. Разве Р. Мертон не критикует

\footnotetext{
${ }_{17}^{17}$ Деррида Ж. Фрейд и сцена письма // Французская семиотика: От Структурализма к постструктурализмy. M., 2000., c. 337;
}

функциональный подход, вызванный к жизни Т. Парсонсом? Но эта его критика лишь способствует развитию и еще большему утверждению функционализма.

Вообще, в свое время формализму тоже был вынесен приговор. Несколько десятилетий в нем невозможно было ни писать, не говорить. И ведь критиком-то формализма были не только марксисты - догматики, а сам М. Бахтин. И что же? Несмотря на эту критику, мы наблюдали в 6о-е годы второе рождение формализма, чему, кстати, способствовал структурализм. Именно тогда стало очевидно, что формализм был предвестием структурализма, первой его ступенью. То общее, что роднит формализм и структурализм, - это, конечно, ориентация на лингвистику. В гуманитарных науках надо было до конца использовать те преимущества, которые имелись в идеях $\Phi$. де Соссюра. А что касается критики семиотического направления, то как Р. Мертон в социологии не перечеркнул ни идеи Т. Парсонса, ни функционализма в целом, так и М. Ямпольский не разрушил семиотический проект в его применении к кино.

Более того, необходимо воспользоваться теми конструктивными идеями, которые имеются в критике семиотики, в частности, тем рациональным зерном, которое имеется, в том числе, и в высказывании М. Ямпольского. Представляется, что разрешение проблемы, которое предпринял М. Ямпольский, - одно из возможных направлений в развитии науки о кино. Присутствующим здесь киноведам известно, что выход М. Ямпольского из структурализма связан с интересом к философии и, в частности, к феноменологии как одному из философских направлений. Он предлагает такую логику науки - от лингвоцентрических моделей смысла в кино к философским и, в частности, феноменологическим моделям. В соответствии с этой логикой им перестраивается логика истории киномысли.

Так, в предисловии к своей книге «Видимый мир. Очерки ранней кинофеноменологии» М. Ямпольский пишет об исчерпанности парадигмы семиотической кинотеории, что, по его мнению, привело к кризису киномысли. Выход из кризиса он видит в возвращении к ранней кинотеории, вытесненной работами о языке кино и монтаже, определившими видение кино с 20-х годов. Конечно, под теми, кто в этом 
вытеснении был виновен, следует подразумевать формалистов и С. Эйзенштейна. «Наше знакомство с десятками забытых ныне работ - пишет он - утвердило нас в убеждении, что домонтажная киномысль немого периода может явиться живым и плодотворнейшим источником для нашего нынешнего движения вперед, для сегодняшней кинорефлексии ${ }^{18}$.

Почему М. Ямпольский так высоко оценивает рефлексию о кино, предшествующую эпохе абсолютизации языка и монтажа в кинотеории? Да потому, что первые теоретики были свободны от той интерпретации, что будет кинотеории навязана методологией изучения вербальных и языковых структур. На ранних этапах эта теория свободна от лингвистических и семиотических моделей. Но ведь что такое структуры языка как не структуры культуры? Значит, абстрагируясь от структур языка, мы уже пытаемся выйти за пределы культуры. Но об этом у М. Ямпольского и идет речь. Необходимо пробиться к очищенным от культуры чувственным, природным, предметным, телесным, видимым стихиям бытия. Это, однако, предполагает и возвращение к тем идеям, которые некогда уже высказывались, например, в романтизме, в философии жизни, в феноменологии, а, может быть, даже еще раньше в неоплатонизме. Высказывались в философии.

Так, анализируя высказывания французских режиссеров о кино, М. Ямпольский усматривает влияние на них философии А. Бергсона и, в частности, той его мысли о возможности «погружения в протосознание, на том этапе человеческой истории, когда человек (Адам) непосредственно понимал язык природы» ${ }^{19}$. И вот вывод М. Ямпольского. «Кинематограф в глазах ранних теоретиков осуществляет то же погружение к первоистине, не затемненной словом и понятием, к речи самой природы, данной нам в абсолютной непосредственности» ${ }^{20}$.

Феноменологическая перспектива и в самом деле заманчива. Призыв преодолеть семиотику и вернуться к ранней теоретической рефлексии о кино соответствует максиме М. Хайдеггера «К самим вещам!». Ведь призывая к вещам, М. Хайдеггер вы-

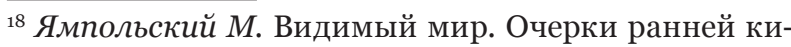
нофеноменологии. М., 1993., с. 4;

19 Ямпольский М. Видимый мир..., с. 38;

${ }^{20}$ Ямпольский М. Видимый мир..., с. 38;
}

ступает «против всех свободно парящих конструкций, случайных находок, против заимствования любых лишь мнимо доказанных концепций, против мнимых вопросов, которые часто на протяжении поколений выпячиваются как «проблемы» ${ }^{21}$.

В какой-то степени это можно считать не только преодолением семиотики, но и научности как таковой, которую семиотика выражает. Не случайно М. Мерло - Понти, чьи идеи определили радикальный пересмотр отношений М. Ямпольского с семиотикой, как он в этом сам признается, формулирует: «Феноменологическая или экзистенциальная философия определяет своей задачей не объяснение мира или выяснение условий его возможности, но выражение опыта мира, контакта с миром, который предшествует любому мышлению о мире» ${ }^{22}$.

Размышляя над выводами, к которым приходит М. Ямпольский, к тем его симпатиям по отношению к глубинным структурам сознания, к протосознанию, к контакту с предметностью, что М. Ямпольский связывает с феноменологией, невольно задаешь себе следующий вопрос: но разве не то же самое интересовало В. В. Иванова в книге о С. Эйзенштейне? А ведь именно эта книга для семиотических экспериментов в 6о-е годы явилась ключевой. Разве не по этой причине С. Эйзенштейна привлекли идеи Л. Выготского, позволяющие реконструировать то, что за словом, раньше слова, помимо слова? Разве не то же самое В. В. Иванов пытается обнаружить в мышлении С. Эйзенштейна, получившем выражение в его фильмах? Потому и возник контакт между С. Эйзенштейном и Л. Выготским, что концепция Л. Выготского, позволяющая понять, как при распаде высших форм логического, понятийного мышления активизируются структуры, напоминающие ранние или архаические формы комплексного мышления ${ }^{23}$. Вот с ними-то С. Эйзенштейн и связывает и структуры чувственного мышления, и форму произведения, и секрет воздействия произведения на публику. Ж. Деррида пытается найти выход за пределами лингвистики с помощью психоанализа Фрейда, В. В. Иванов ведет свои ${ }^{21}$ Шпигельберг Г. Феноменологическое движение. M., 2002., c. 341 ;

${ }^{22}$ Шпигельберг Г. Указ. соч., с. 440;

${ }^{23}$ Иванов В. Эстетика Эйзенштейна // Избранные труды по семиотике и истории культуры. , т. 1., с. 754; 
поиски с помощью С. Эйзенштейна, обнаружившего в иероглифическом письме истоки кинематографической речи.

Bсе то же самое интересует в С. Эйзенштейне и В. В Иванова, но только все это у С. Эйзенштейна получает прикладной характер, а у В. В. Иванова семиотическое истолкование. Причем, не только исключительно семиотическое, но, в том числе, и психологическое истолкование. Ведь он постоянно привлекает к объяснению не только Л. Выготского, но, скажем, Э. Кречмера. Тут возникает тот самый аспект взаимоотношений между семиотикой и психологией, который как раз и обсуждался на конференции, посвященной юбилею выдающегося ученого-гуманитария.

Более того, каждый, кто внимательно читал книгу В. В Иванова, а, тем более, тексты самого С. Эйзенштейна, помнит, как часто в ней упоминается имя Л. Леви - Брюля, который одним из первых начал заниматься структурами пралогического мышления, т.е. тем самым «протосознанием», о котором говорит М. Ямпольский. Несомненно, Л. Леви - Брюль повлиял на представления о монтаже С. Эйзенштейна. В. В. Иванов отдает ему должное. Но ведь вот что интересно. Сам Э. Гуссерль, вызвавший к жизни феноменологию, признавал, что именно Л. Леви - Брюль проделал то, что его, феноменолога, и интересует. Так, в письме 1935 года Э. Гуссерль заявил, что Л. Леви - Брюль предвосхитил его концепцию на практике, открыв путь для подлинной науки о социальных и культурных проблемах ${ }^{24}$. Это свидетельствует о том, какие случаются совпадения между разными исследовательскими направлениями и науками.

Как из сказанного следует, преодоление отсутствия философского фундамента М. Ямпольским мыслится исключительно с помощью феноменологии. Наверное, если двигаться этим путем, то в границах философии возможны и другие подходы. Какие? Автор не случайно много внимания уделил М. Ямпольскому. Все дело в том, что философский подход имеет место и в исследовании В. В. Иванова о С. Эйзенштейне. Этому удивляться не приходится. Поскольку, как уже отмечалось, В. В. Иванова тоже интересует протосознание только применительно к экспериментам С. Эйзенштейна.

\footnotetext{
${ }^{24}$ Шпигельберг Г. Указ. соч., с. 167;
}

Обратим внимание на то, что книга о С. Эйзенштейне называется «Эстетика Эйзенштейна». Именно эстетика, а не семиотика. Но ведь что такое эстетика как не одно из направлений философии? Эстетика - это философская дисциплина. Так мы привыкли к ней относиться со времен Канта. Поэтому то, что М. Ямпольский подразумевает под новым проектом, преодолевающим семиотический проект, совсем не является новым. Как свидетельствует уже название книги В. В. Иванова, семиотика с самого начала подразумевала философию. Философский аспект знака и вообще семиотики в эстетическом проекте подразумевался с самого начала, т.е. с начала возникновения философии, т.е. с начала возникновения философии модерна, когда европейская культура начала дрейфовать в сторону не текста, а грамматики.

Мы не зря вспомнили идею теории культуры Ю. Лотмана. Хочется последовательно провести мысль о том, что возникновение семиотического проекта с самого начала явилось проблемой культуры, а, следовательно, первыми об этом начали отдавать отчет философы. Просто в силу того, что в 1-й половине XX века лингвистика среди гуманитарных дисциплин выдвигалась в лидеры, семиотический проект реализовывался в заданной Ф. де Соссюром традиции. Этому способствовало и то обстоятельство, что самыми яркими работами в границах этого проекта оказались, действительно, работы филологов, будь то Ю. Тынянов или Ю. Лотман. Но прежде всего, конечно, В. В. Иванов.

В силу каких - то причин (хотя они лежат на поверхности) философский аспект семиотики был менее разработан, хотя постоянно подразумевался. Так, М. Бахтин, выходя за пределы лингвистической ориентации и ставя функционирование знаковых систем в зависимость от изменяющегося положения субъекта в мире, которому В. В. Иванов уделяет в своей книге много внимания, тоже пытается предложить философское осмысление функционирования знака. В частности, он много говорит о близости приемов, используемых С. Эйзенштейном, к идее М. Бахтина о карнавальном сознании. Особенно это касается фильма С. Эйзенштейна «Иван Грозный», в частности, использования в фильме архетипической ситуации обмена одеждой 
между царем и подданным Владимиром Старицким ${ }^{25}$.

Так, если уж аргументировать, почему B. В. Иванов в названии своей книги о С. Эйзенштейне использовал понятие не семиотики, а эстетики, то, видимо, здесь тоже следует иметь в виду присутствие философского аспекта. Ведь эстетика и семиотика в культуре грамматики возникают одновременно. Идея семиотики впервые появилась не у лингвиста $\Phi$. де Соссюра в начале XX века, а у философа А. Баумгартена в середине XVIII века. Как всем известно, А. Баумгартен первым вызвал к жизни проект эстетической науки, хотя этот проект мы связываем обычно с именами Канта и Гегеля. Предметом эстетики для А. Баумгартена как раз и является чувственное мышление, которое, как считал С. Эйзенштейн, соответствует ранним формам мышления ${ }^{26}$. Так вот, крестный отец эстетики А. Баумгартен вообще считал семиотику частью эстетики, т.е. философии искусства. Эстетику он делил на теоретическую и прикладную. В теоретической же эстетике он выделял три основные проблемы - эвристики, методологии и изучающей знаки семиотики ${ }^{27}$.

В связи с этим вернемся снова к атмосфере 6о-х годов, когда дискуссии о структурализме и семиотике достигают апогея. Обратим внимание на то, что именно в этот период находятся на подъеме и эстетика ${ }^{28}$. Очень похоже, что активизация эстетики происходила под воздействием того нового знания, что приносила семиотика. Таким образом, семиотика, во всяком случае, семиотика искусства развивается как часть философии искусства или эстетики.

Эту связь между эстетикой и семиотикой констатирует и Ж. Деррида. «Раз искусство существует посредством знака, - пишет он а его действительность определяется подражанием, оно может функционировать лишь в системе культуры, а теория искусства выступает как теория нравов. «Нравственное»

\footnotetext{
${ }^{25}$ Иванов В. Эстетика Эйзенштейна.. с. 343;

${ }^{26}$ Эйзенштейн $C$. Избранные произведения в 6 т., т. 2., М., 1964., c. 113;

${ }^{27}$ История эстетики. Памятники мировой эстетической мысли в 5 т., т. 2. Эстетические учения XVII XVIII веков., М., 1964., с. 455;

${ }^{28}$ Хренов Н. Эстетический Ренессанс эпохи оттепели // Экспериментальное искусство. Влияние теории на художественное творчество. Под редакцией О. Личчиарделло, С. Ломбардо, В. Петрова., М., 2011., с. 39;
}

впечатление, в отличие от «чувственного» впечатления, передает свою силу знаку. Эстетика проходит через семиологию и даже этнологию. Воздействие эстетических знаков может быть определено лишь внутри культурной системы» ${ }^{29}$.

Мы, конечно, заострили проблему, утверждая, что вопрос о семиотике применительно е искусству первым поставил А. Баумгартен. Как показал В. В. Иванов в другой своей работе «Очерки по предыстории и истории семиотики», идеи о необходимости изучения знаков были уже у Лейбница и Локка, а в XVIII веке, когда А. Баумгартен предложил проект эстетики, семиотика, как пишет В. В. Иванов, становится признанной дисциплиной ${ }^{30}$. Когда мы говорим, что А. Баумгартен был первым, то имеем в виду то, что первым он был в постановке вопроса о том, что семиотика является частью эстетики, входит составной частью в эстетику.

Однако если уж проводить параллели, то обращение В. В. Иванова к С. Әйзенштейну, кино и вообще к искусству скорее напоминает историю с Кантом. Для Канта эстетика хотя и стала в истории гуманитарной науки выдающимся явлением, но далеко не исчерпывала всего его философского наследия. Пытаясь постичь метод С.Эйзенштейна, В. В. Иванов в своей книге исходит из того же, из чего исходили основатели эстетики - из необходимости рациональным, научным способом постичь чувственную, иррациональную стихию. Особенно четко эта тема прописана в главе «Моцарт и Сальери», где в связи с С. Эйзенштейном говорится о рационально постигаемой стороне искусства, почему, собственно, возникают и эти архетипы Моцарта и Сальери, которые затем трансформируются в ницшевских Диониса и Аполлона. В образах богов представлена идея двуединства искусства. Так, Дионис соответствует пралогике, Аполлон - логике («Диффузное и отчетливое. Сумеречное и ясное. Животностихийное и солнечно-мудрое» ${ }^{31}$. Правда, В. В. Иванов утверждает, что такое противопоставление весьма условно, ведь даже у самого Моцарта есть нечто от Сальери. Комментируя это, В. В. Иванов пишет: «И

\footnotetext{
${ }_{29}$ Деррида Ж. О грамматологии. М., 200о., с. 373;

${ }^{30}$ Иванов В. Очерки по предыстории и истории семиотики., с. 638 ;

${ }^{31}$ Иванов В. Эстетика Эйзенштейна., с. 302;
} 
это не просто курьез: наиболее одаренные люди искусства нередко были сторонниками проникновенного и строгого научного его исследования, требующего не меньше изобретательности и бесстрашия, чем создание самого искусства» ${ }^{2}$.

Но этот же вопрос о возможности изучения искусства с помощью науки и, в частности, философии впервые задан Гегелем в его «Эстетике». Естественно, что ответ на этот вопрос был положительным. «Хотя создания искусства представляют собой не мысль и понятие, а развитие понятия из самого себя, его переход в чуждую ему чувственную сферу - пишет Гегель - все же сила мыслящего духа заключается в том, что он постигает самого себя не только в собственно своей форме, в мышлении, но узнает себя и в своем внешнем и отчужденном состоянии, в чувстве и чувственности, постигает себя в своем инобытии, превращая отчужденное в мысли и тем возвращаясь к себе» ${ }^{33}$. Таким образом, следуя В. В. Иванову, можно считать, что С. Эйзенштейн явился продолжателем тех идей, что впервые были высказаны Гегелем, Шеллингом и другими основателями эстетической науки.

Но дело не только в способности С. Эйзенштейна подхватывать и разрабатывать идеи, что высказывались пионерами эстетической науки. Дело еще и в том, что предмет, который интересовал С. Эйзенштейна, а именно, кино разрешению этих идей благоприятствовал. Вот как пишет об этом В. В. Иванов. «По мнению С. Эйзенштейна, - пишет он - кино открывает не только невиданные возможности в самом искусстве, но вместе с тем позволяет открыть и проверить основополагающие эстетические законы» 34 .

Таким образом, утверждая, что С. Эйзенштейн предваряет современные семиотические исследования, В. В. Иванов все же акцент ставит на разрешении С. Эйзенштейном эстетической проблематики. Когда мы говорим о разрешении С. Эйзенштейном эстетической проблематики, то, что это означает? Это означает проникновение в иррациональные сферы с помощью рациональных подходов. Но что это означает для С. Эйзенштейна? Ведь фило-

\footnotetext{
${ }^{32}$ Иванов В. Эстетика Эйзенштейна., с. 185;

33 Гегель. Эстетика. Т. 1. М., 1968., с. 19;

${ }^{34}$ Иванов В. Эстетика Эйзенштейна., с. 199;
}

софы модерна, вызвавшие к жизни эстетику, сформулировали лишь общие идеи. Что конкретно С. Эйзенштейн вносит в эти идеи? И позволяет ли эстетика и семиотика С. Эйзенштейна утверждать, что им сделан существенный вклад в познание иррациональных стихий искусства? Здесь, конечно, не избежать разговора об энциклопедических познаниях С. Эйзенштейна и его способностях при разработке языка нового искусства использовать данные самых разных научных дисциплин от психоанализа и гештальтпсихологии до культурно - исторической психологии и, в том числе, семиотики. Это обстоятельство, кстати, сделало затруднительным освоение его теоретического наследия нашими киноведами. Прокомментировать это оказалось под силу лишь В. В. Иванову.

Синтез всех своих познаний, видимо, совершается в его завершающей работе С. Эйзенштейна «Основная проблема» (Grundproblem), смысл которой, как формулирует В. В. Иванов, заключается в том, что искусство связано с регрессом к низшим слоям сознания. Характеризуя эту работу, обозначаемую С. Эйзенштейном то как «Метод», то как «Основная проблема», он пишет: «В книге доказывается, что форма, без которой искусство невозможно, может повлиять на зрителя или читателя только в том случае, если она адресуется к нижним слоям психики, к иррациональному в нем» 35 . В главе, посвященной «Основной проблеме», он говорит, что основная проблема психологической теории искусства С. Эйзенштейна состоит в том, что искусство предполагает как участие высших ступеней сознания, так и проникновение через строение формы в слои глубинного чувственного мышления («Воздействие на зрителя или слушателя возможно лишь при условии, что самой формой произведение обращено к этим глубинным архаичным слоям сознания. Оно от них неотделимо и поэтому может подвергнуться самой жестокой критике тех высших слоев сознания, участие которых в современном искусстве желательно, но не всегда осуществимо» ${ }^{36}$.

Таким образом, усилия С. Эйзенштейна, прокомментированные и осмысленные В. В. Ивановым (ведь «Основная проблема» С. Эйзенштейна долгое время в окон-

35 Иванов В. Эстетика Эйзенштейна., с. 147;

${ }^{36}$ Иванов В. Эстетика Эйзенштейна., с. 287; 
чательном виде оставалась неизвестной), связаны с выявлением структуры того, что заложено уже в самом понятии эстетики, т.е. структуры чувственного мышления и восприятия. Лишь в XX веке, благодаря усилиям психологов, представляющих психоанализ, аналитическую психологию, культурно - историческую психологию, как и усилиям семиотиков, мы стали точнее и глубже представлять, что такое чувственное мышление. Но приходится констатировать, что эти усилия, ставшие в XX веке возможными благодаря успехам самых разных наук, не всегда были осмыслены в границах философии.

В процитированных суждениях В. В. Иванова часто говорится о форме, тесно связанной со спецификой чувственного мышления. И здесь возникает проблема обсуждаемого в разных источниках совпадения и несовпадения подходов формалистов и С. Эйзенштейна, чего не мог, естественно, обойти и В. В. Иванов. Ведь если, как получается, и формалисты, и С. Эйзенштейн предвосхитили структурализм, то между ними просто не могло не быть точек соприкосновения. Формалистов и С. Эйзенштейна объединяет общее устремление эпохи - отношение к культуре, воспроизводящей модель грамматики. Именно акцент на модель грамматики стало причиной обращения к эстетике, но на этот раз даже не к эстетике XVIII века, родившейся в недрах философии модерна, а к античной эстетике в ее аристотелевском варианте. А для этого варианта характерен интерес к конструкции вещи, к структуре, что и изложено в «Поэтике « Аристотеля.

Когда О. Хансен - Леве анализирует логику становления формальной школы, он начинает с эстетики, но не с просветительской эстетики XVIII века, а с античной эстетики и, еще более точно, с эстетики Аристотеля. Это вообще может показаться парадоксальным, поскольку сами формалисты, как уже отмечалось, всячески открещивались и от эстетики, и от философии. Тем не менее, констатируя возникший в XX веке новый интерес к построению поэтики, что со времен Аристотеля стало традицией, О. Хансен - Леве пишет: «Поэтика Аристотеля не случайно была одним из наиболее читаемых и обсуждаемых произведений в области теории литературы в 10 - 20-е годы XX века (в России в том числе), более того, можно говорить о ренессансе аристо- телевского наследия в современном искусствознании и эстетике, правда, приведшем к достаточно различным новым оценкам. Так, русских формалистов интересовала не столько теория мимесиса, сколько его признание конструктивной автономии поэзии и следующей из этого необходимости имманентного анализа, который бы разбирал, подобно логике и риторике, поэтические произведения в их целостности и цельности на предмет соответствующих технических приемов» ${ }^{37}$.

Смысл формализма можно свести к устойчивой традиции в эстетике - время от времени возрождающемуся стремлению построить очередной вариант поэтики. В обсуждении этого совпадения мы на первый план выдвинем проблематику формы в ее соотнесенности со спецификой чувственного мышления. Посвящая свой обзор генезису и становлению формальной школы и реагируя на суждения по поводу того, что русскому искусству проблема формы вообще чужда, Р. Якобсон рассуждает так. На этом фоне формализм воспринимается беспрецедентной новацией. Но такую постановку вопроса Р. Якобсон отвергает. Утверждая, что в русском искусстве чрезвычайно активна византийская традиция, а в ней форма весьма активна. Именно в эпоху появления формальной школы были заново открыты формальные достоинства византийского и древнерусского искусства ${ }^{38}$.

Но формальная школа привлекает к себе не этим, Ведь, по сути дела, в ее появлении, как бы сами формалисты не открещивались от философии и эстетики, проявились отзвуки кантовской реформы философии - приблизить к философии естественные науки. В экспериментах формалистов и структуралистов витает дух позитивизма. В начале XX века казалось, что ближе всего к настоящей научности, т.е. к естественным наукам находится лингвистика. Причиной того, почему в семиотике не был или слабо был разработан философский аспект, о чем пишет М. Ямпольский, является вовсе не сама семиотика и не лингвистика, а, в том

37 Ханзен-Леве О. Русский формализм. Методологическая реконструкция развития на основе принципа остранения. М., 2001., с. 17;

${ }^{38}$ Якобсон Р. Формальная школа и современное русское литературоведение. М., 2011., с. 14; 
числе, и философия, а точнее, кризис, охвативший в XX веке философию. Сама она вынуждена была обращаться к лингвистике. Не случайно Ю. Кристева говорит, что семиотика стремится стать таким дискурсом, который сможет потеснить метафизическую речь философа благодаря строгости своего научного языка, способного создавать различные модели социального функционирования (различных семиотических практик)» 39.

Что делать, если в XX веке частные науки оказываются подчас более плодотворными и привлекательными, чем философия и эстетика, что нередко приводит к дистанцированию и от философии, и от эстетики. Об этом дистанцировании от эстетики и философии формального метода Б.Эйхенбаум говорит так: «Представителей формального метода неоднократно и с разных сторон упрекали в неясности или в недостаточности их принципиальных положений - равнодушии к общим вопросам эстетики, психологии, философии, социологии и т.д. Упреки эти, несмотря на их качественные различия, одинаково справедливы в том отношении, что они правильно схватывают характерный для формалистов и, конечно, не случайный отрыв как от «эстетики сверху», так и от всех готовых или считающих себя такими общих теорий. Этот отрыв (особенно от эстетики) - явление более или менее типичное для всей современной науки об искусстве. Оставив в стороне целый ряд общих проблем (вроде проблемы красоты, цели искусства и т.д.), она сосредоточилась на конкретных проблемах искусствознания» ${ }^{40}$.

Но это совсем не означает, что отныне так будет всегда. Это только характеризует ту, как выражается М. Фуко, эпистему, которая характерна для XX века. Значит, можно надеяться, что семиотика еще будет переживать эпоху расцвета. И тут самое время сказать о том, что мы все время спешим с выводами и категорическими заключениями по поводу кризиса, а то и того хуже, краха какой-то науки, в данном случае, семиотики. Следовало бы внимательно осмыслить те фазы, которые проходит становление всякой науки, в том числе, гу-

\footnotetext{
${ }^{39}$ Кристева Ю. Указ. соч., с. 78;

40 Эйхенбаум Б. Теория «формального метода»// Эстетика и теория искусства XX века. Хрестоматия. Ответственные редакторы Н. Хренов, А. Мигунов, М., Прогресс - Традиция., 2007., с. 387;
}

манитарной. Когда Б. Эйхенбаум пытается представить становление формального метода во времени, он подчеркивает, что такой подход не является застывшим. «Мы окружены эклектиками и эпигонами, превращающими формальный метод в некую неподвижную систему «формализма», которая служит им для выработки терминов, схем и классификаций, - пишет он - Эта сторона очень удобна для критики, но совершенно не характерна для формального метода. Никакой такой готовой системы или доктрины у нас не было и нет» ${ }^{41}$.

В плане преодоления такого представления о формализме как раз и навсегда данном, застывшем методе показательна попытка О. Хансен - Леве выявить в эволюции формального подхода три фазы. Видимо, это важно проделать и применительно к С. Эйзенштейну. В. В. Иванов не обходит вопроса об отношениях формальной школы и С. Эйзенштейна, вернее, поэтики в ее разных вариантах - формалистской и эйзенштейновской. Многие констатируют между ними несовпадения. Но если С. Эйзенштейна представлять предтечей семиотики, то, как уже отмечалось, совпадения, разумеется, неизбежны, и их можно фиксировать.

Но есть и существенные расхождения. Так, В. В. Иванов обращает внимание на расхождения. «Признавая ценность открытия приема в ОПОЯЗе, он (Эйзенштейн - Н. Х.) оставался далек от взглядов его членов, в том числе, и от опытов понимания кино, предложенных формалистами» 42. Однако у В. В. Иванова в формулировке этих несовпадений отсутствует категоричность. Он говорит о частичной созвучности интересов С. Эйзенштейна, с одной стороны, и В. Шкловского и Ю. Тынянова, с другой. Расхождение, однако, очевидно в отношении к сюжету. Так, формалисты занимаются сюжетосложением, а ранний С. Эйзенштейн сюжет отрицает вообще, ставя акцент на монтаже аттракционов. Комментируя эту проблему, В. В. Иванов пишет: «От сюжета как такового он (Эйзенштейн - Н. Х.) хочет отвлечься». Он пишет: «Под аттракционом понималась единица или первичный элемент спектакля (а при дальнейшем развитии теории по отноше-

\footnotetext{
${ }^{41}$ Эйхенбаум Б. Теория «формального метода» // Эстетика и теория искусства XX века. Хрестоматия. Ответственные редакторы Н. Хренов, А. Мигунов, М., Прогресс - Традиция., 2007., с. 387 ;

${ }^{42}$ Иванов В. Эстетика Эйзенштейна., с. 281;
} 
нию к кино - и фильма), оцениваемая с точки зрения реакции зрителя. Основой всей концепции Эйзенштейна был перенос центра тяжести на восприятие спектакля или фильма. Эта сторона остается неизменной на протяжении четверти века, отделяющей первые теоретические статьи о монтаже аттракционов от программы курса по теории выразительности, написанной Эйзенштейном перед смертью для психологического факультета МГУ по предложению Лурия» 43. В другом месте В. В. Иванов пишет: «Если для формалистов в их понимании сюжета основным было его противопоставление фабуле, то Эйзенштейну важна причина особого воздействия внесюжетных вещей, обусловленная принципами их построения» 44. Идея интеллектуального кино С. Эйзенштейна связана в принципе с бессюжетной конструкцией. Но на разных этапах расхождения между формалистами и С. Эйзенштейном стирались.

Чтобы выявить, что сближает С. Эйзенштейна с формалистами, воспользуемся выделением О. Хансен - Леве в становлении метода формальной школы несколько этапов или фаз. Методология формальной школы не возникла в один момент. Ее становление происходило во времени. О. Хансен - Леве выделяет три фазы. На первой фазе акцент ставится на отграничении художественного ряда от нехудожественного, что спровоцировало абстрагирование от существующей эстетики и методов других дисциплин, в частности, от психологии. Естественно, что формальная школа берет курс на лингвистику, перенося лингвистический подход на поэтику ${ }^{45}$. В этом формализм предвосхищает структурализм.

Что касается обособления художественного ряда от нехудожественного, то по этому поводу Р. Якобсон писал, что отныне предметом науки о литературе является не литература, а литературность, Лишь это и обеспечивает то, что данное произведение является литературным произведением. «Между тем - пишет Р. Якобсон - до сих пор историки литературы преимущественно уподоблялись полиции, которая, имея целью арестовать определенное лицо, захватила бы на вся-

\footnotetext{
43 Иванов В. Эстетика Эйзенштейна., с. 167;

${ }^{44}$ Иванов В. Эстетика Эйзенштейна., с. 283;

45 Медведев П. Формальный метод в литературоведении. Л., 1928., с. 118;
}

кий случай и все, что находилось в квартиpe, a также случайно проходивших по улице мимо. Так и историкам литературы все шло на потребу: быт, психология, политика, философия. Вместо науки о литературе создавался конгломерат доморощенных дисциплин. Как бы забывалось, что эти статьи отходят к соответствующим наукам - истории философии, истории культуры, психологии и т.д. - и что последние могут, естественно, использовать и литературные памятники как дефектные, второсортные документы» 46 .

На второй фазе внимание сосредоточено на синтаксическом или, еще точнее, синтагматическом аспекте, на конструкции, что созвучно структуралистским представлениям. В этом тоже можно усмотреть предвосхищение структурализма. Наконец, на третьей фазе интерес сосредотачивается на диахронии, т.е. на функционировании синхронических структур в историческом времени, что потребовало углубиться в рецептивную проблематику, в историческую поэтику, историю литературы и т.д. Тут, как представляется, формалисты идут на сближение с М. Бахтиным.

Но в связи с С. Эйзенштейном не может не заинтересовать следующий вопрос. Те выводы, которые делает С. Эйзенштейн относительно чувственного мышления, требуют особой интерпретации, а именно, культурологической интерпретации. Структура чувственного мышления с его пралогикой соотносима не только с конкретными произведениями искусства и не только с сознанием конкретных художников. Это не только проблема эстетики, для которой значимы и чувственная реальность, и глубины чувственного мышления. В «Методе» С. Эйзенштейн пишет: «Особенность нашей психологической структуры состоит в том, что живем мы всеми слоями одновременно - каждый управляет своим разделом деятельности от неконтролируемых сознанием «непроизвольных автоматизмов» до высших проявлений сознания и воли. В зависимости от ситуации и необходимости мы действуем и любим из них в качестве «ведущего» 47. В другом месте

\footnotetext{
46 Якобсон Р. Новейшая русская поэзия. Набросок первый: Подступы к Хлебникову // Якобсон Р. Работы по поэтике. М., 1987., с. 273;

47 Эйзенштейн С. Метод., т. 1. Grundproblem. М., 2002., c. 323;
} 
С. Эйзенштейн свою мысль формулирует кратко: «Но внутри нас действуют все слои» ${ }^{48}$. Конечно, такая формулировка выдает знакомство С. Эйзенштейна с культурно - исторической школой в психологии.

Но можно ли такое представление о психологической структуре исчерпать лишь индивидуальной психологией? Нельзя ли приложить этот механизм участия всех уровней сознания к функционированию культуры? Здесь возникает вопрос о взаимоотношениях психологии и культурологии. В данном случае нам может помочь не столько почитаемый ранним С. Эйзенштейном 3. Фрейд, сколько разошедшийся с 3. Фрейдом К. Юнг. Ведь та же самая структура, вероятно, присуща не только личности, но и культуре, в которой личность существует и от которой она зависит.

Не случайно применительно к каждой, а не только русской культуре Н. Бердяев сформулировал принцип одновременного функционирования структур, возникавших в истории последовательно. Философ настаивает, что это характерно особенно для России. Эту мысль следовало бы уточнить. Это было особенно характерно для России $\mathrm{XX}$ века, когда в ходе революций разрушались привычные стереотипы поведения и мышления и в соответствии с концепцией Л. Выготского активизировались их древние структуры. «Россия - пишет Н. Бердяев - совмещает в себе несколько исторических и культурных возрастов, от раннего Средневековья до XX века, от самых первоначальных стадий, предшествующих культурному состоянию, до самых вершин мировой культуры. Россия - страна великих контрастов по преимуществу, - нигде нет таких противоположностей высоты и низости, ослепительного света и первобытной тымы. Вот почему так трудно организовать Россию, упорядочить в ней хаотические стихии. Все страны совмещают много возрастов. Но необъятная величина России и особенности ее истории породили невиданные контрасты и противоположности. У нас почти нет того среднего и крепкого общественного строя, который повсюду организует народную жизнь» 49 .

Можно было бы попытаться в русской культуре обнаружить активность двух оп-

\footnotetext{
48 Эйзенштейн С. Метод., т. 2. Тайны мастеров. М., 2002., c. 568;

49 Бердяев Н. Судьба России. Опыты по психологии войны и национальности. М., 1918., с. 71;
}

ределяющих слоев - того, что возник в эпоху модерна, для которого характерна идея радикальной перестройки общественного бытия и того, что возник как реакция на модерн, как сопротивление модерну. Он связан с мировосприятием романтиков. Во многом мы остаемся еще модернистами. Мы уже касались того, что в ряде своих работ Ю. Лотман пытается описать два типа культуры ${ }^{50}$. Один тип соотносим с определенной суммой прецедентов и текстов как образцов для последующего повторения. Другой тип соотносим с совокупностью создаваемых норм и правил, в соответствии с которыми порождаются новые тексты. Иначе говоря, культура первого типа является культурой текстов, а вторая - культурой грамматики. Но ведь эти типы могут сосуществовать или сменять друг друга в одной и той же культуре. Ю. Лотман этого не отрицал.

Так вот, культура Просвещения или вообще та, что следует этой традиции - это есть культура грамматики. Не следовать уже установленным образцам, а создавать новые правила. Собственно, именно эта парадигма, которая является уже общекультурной, активно внедряется в сознание на протяжении последних столетий. В искусстве она наиболее ярко проявилась в первой половине XX века, о чем и свидетельствует интерес к распространившейся на искусство лингвистической и семиотической модели. Другая - альтернативная культура начала себя осознавать в границах романтизма. Ее не назовешь футуристической, скорее пассеистической. Не случайно по отношению к модерну она оказалась оппозиционной. Совершенно не случайно в этой культуре реабилитируется Средневековье.

Как это происходит, попытался объяснить Г. Федотов, задумываясь об активизации в ходе революции наиболее древних пластов культуры. Имея в виду спровоцированные революцией геологические сдвиги, он пишет: «Сперва подпочвенная, болезненно сжатая, но древняя традиция выходит наружу, сказываясь не столько в реставрациях, сколько в самом модернистском стиле воздвигаемого здания. Однако старина эта бывает не похожа на недавнее,

\footnotetext{
5о Лотман Ю. Проблема «обучения культуре» как ее типологическая характеристика // Труды по знаковым системам. Выпуск 5. Тарту., 1971., с. 168;
} 
только что убитое прошлое. Из катастрофы встают ожившими гораздо более древние пласты» ${ }^{51}$. Так, Г. Федотов показал, что тип массового человека, что реализовал себя в эпоху Сталина, был сформирован именно в средние века. Так, в первой половине $\mathrm{XX}$ века этот тип вышел из подполья, готовый к новой попытке построения крепкой государственности «третьего Рима».

В. В. Иванов затрагивает вопрос о взглядах С. Эйзенштейна и П. Флоренского по поводу перспективы, организации пространства в изобразительном искусстве ${ }^{52}$. П. Флоренский, многое сделавший в плане реабилитации средневековой перспективы, вообще приходил к выводу о чередовании в истории двух типов культуры - той, что получила выражение в Средние века и той, что начала становление еще в эпоху Ренессанса. Эта концепция П. Флоренского предвосхищает идею социодинамики П. Сорокина. Оба этих типа - и тип культуры модерна, возникший в эпоху Просвещения, и тип культуры, получивший выражение в романтизме, в русской культуре можно констатировать существующими одновременно. Но сознанием этой культуры является все-таки модерн, о чем и свидетельствуют три революции в ее истории. В XX веке Россия продемонстрировала реализацию одного из самых радикальных проектов преобразования общества, возникших в эпоху раннего модерна, т.е. в XVIII веке. Но все это связано с высшим уровнем сознания.

Что же касается той структуры чувственного мышления, который интересовал С. Эйзенштейна (и не мог не интересовать, поскольку, как показано в книге В. В. Иванова, многие его фильмы оказывались заказными, и его деятельность контролировалась самим Сталиным), то она иррациональна. Она связана с подсознанием. В. В. Иванов перечисляет все имевшие место контакты С. Эйзенштейна со Сталиным. Как выясняется, С. Эйзенштейн был замечен диктатором еще в пору создания фильма «Броненосец Потемкин». Сталин смотрит отснятые части незавершенного фильма «Октябрь», меняет название фильма «Генеральная линия», дает премии двум историческим

\footnotetext{
${ }_{51}$ Федотов Г. Судьба и грехи России. Избранные статьи по философии русской истории и культуры., т. 2., СПб., 1992., с. 164;

$5^{2}$ Иванов В. Эстетика Эйзенштейна., с. 187;
}

фильмам С. Эйзенштейна и по его вине остался несмонтированным фильм о Мексике. Наконец, не следует забывать о запрете Сталина на вторую серию «Ивана Грозного». Так, В. В. Иванов констатирует «постоянное присутствие Сталина в биографии Эйзенштейна» ${ }^{3}$. Но присутствие Сталина, конечно, вовсе не означает реализацию просветительской модели. Совсем наоборот, эпоха Сталина - это выход в верхние слои сознания как раз архаических комплексов и моделей поведения. Это иррациональная линия, берущая начало в романтизме, а, еще точнее, в Средневековье. Поэтому просветительский проект радикального переустройства общества с помощью революции в России продемонстрировал структуры средневекового сознания.

Вот этими архаическими структурами уже не только искусства, а культуры в целом и пытался овладеть С. Эйзенштейн. Именно поэтому С. Эйзенштейн так тяготел к мифу. Эта мифологизация истории, как показал В. Паперный в своей книге «Культура Два», в XX веке развертывалась в самой жизни. Встречающееся на страницах сочинений C. Эйзенштейна понятие регресса можно интерпретировать уже применительно к культуре. То «сползание с уровня высших форм сознания», о котором пишет С. Эйзенштейн, возможно уже в социальном смысле. Так, С. Эйзенштейн, имея в виду Германию времен Гитлера, говорит о сползании целой страны на уровень Средневековья. «Когда же происходит оползень в социальной системе и сознании государства, то, как ни чудно, но снова - уже всерьез - начинают зловеще пылать костры Средневековья... - пишет С. Эйзенштейн Мы говорили: «возрождение» Средневековья. Но вернее сказать - возврат и регресс в средние века. Мы наблюдаем сползание с уровня наших норм сознания, когда имеем дело с индивидуальной вспышкой сильного аффекта у женщины, выкалывающей глаза на фотографии, или тогда, когда имеем дело с социальным регрессом, когда целая страна - Германия - сползает на уровень Средневековья» 54.

И, кстати сказать, интерес С. Эйзенштейна к мифу роднит его не только с футуризмом и, следовательно, с авангардом, а с символизмом, который в России возникал

53 Иванов В. Эстетика Эйзенштейна., с. 290;

${ }^{54}$ Иванов В. Эстетика Эйзенштейна., с. 290; 
как новое рождение романтизма. Правда, В. В. Иванов констатирует не близость С. Эйзенштейна символизму, а совсем наоборот. «Он (Эйзенштейн - Н. Х.) - пишет он - начал описывать искусство в производственных терминах, противопоставляя их возвышенному словарю символического обожествления искусства» ${ }^{55}$. Этот момент, естественно, свидетельствует о сближении с формалистами и расхождением с символистами. Но порвать связи С. Эйзенштейна с символизмом невозможно. С. Эйзенштейна и символистов объединяет интерес к мифу. Так, В. В. Иванов констатирует объединяющую все фильмы С. Эйзенштейна «сознательную подмену истории мифом» ${ }^{56}$. В его книге есть упоминание в связи с фильмом о Мексике о попытке мифологизированного воссоздания истории Мексики 57. Там есть такая констатация: "На перемены в стране и мире в начале 30-х годов С. Эйзенштейн реагировал как художник - сперва полным отказом от искусства, потом опытами сатирической (в «M.M.M.») или трагической (в «Бежином луге») мифологизации действительности, затем полным уходом от этой действительности в мифологизированную русскую историю последних музыкальных фильмов» 58 .

Футуристы, от искусства которых отталкивались формалисты, в отличие от символистов, не рефлексировали о мифе. Они его творили. Но оказалось, что получился совсем не тот миф, о котором грезили символисты. С. Эйзенштейн как представитель авангарда в формах кино тоже оказался в эпицентре мифологического коллективного сознания, которое выходило за границы искусства. Активизация мифологического сознания охватывает весь социум. Это хо- рошо показал в своей книге В. Паперный на примере архитектуры сталинской эпохи. Активизация мифа в самом социуме приводит к тому, что культура грамматики угасает. Сталинская эпоха означает возвращение к культуре текстов. В. Паперный улавливает этот переход к «культуре Два», в которой подхватываются усилия эпохи Александра III, направленные на поиски собственных корней ${ }^{59}$. Но значение трудов С. Эйзенштейна заключается в том, что он старается рационально постичь соскальзывание целого общества на более ранние уровни мышления.

Так, В. В. Иванов предлагает интерпретацию стихотворения О. Мандельштама «Ламарк», созвучную идее Ф. Ницше о возможном в будущем падении человечества в варварство, которая была подхвачена некоторыми философами Серебряного века 6о. В связи с этим он пишет: «Сейчас можно высказываться более определенно: стихотворение «Ламарк» допускает и такое историческое и социальное прочтение, при котором спуск вниз по ступеням эволюционной лестницы означает и сползание вниз, перечеркивающее всю культуру. Видение возврата к ранним стадиям эволюции в ту пору не только не было асоциальным: оно могло явиться только тому художнику, который слышал пульс времени» ${ }^{61}$.

Заканчивая анализ некоторых центральных идей книги В. В. Иванова о С. Эйзенштейне, подчеркнем еще раз тесную связь семиотического подхода с культурологической рефлексией. Эти науки не противостоят, а дополняют друг друга. Это обстоятельство и обращает на себя внимание в книге Вячеслава Всеволодовича Иванова о С. Эйзенштейне.

\section{Библиография:}

1. Автономова Н. Деррида и грамматология// Деррида Ж. О грамматологии. М., 2000;

2. Бердяев Н. Судьба России. Опыты по психологии войны и национальности. М., 1918;

3. Гегель Г.Эстетика. т.1., М. 1968;

4. Деррида Ж. Структура, знак и игра в дискурсе гуманитарных наук // Французская семиотика: От структурализма к постструктурализму. М., 2000;

5. Деррида Ж. Театр жестокости и завершение представления // Французская семиотика; От структурализма к постструктурализму. М., 2000;

\footnotetext{
55 Иванов В. Эстетика Эйзенштейна., с. 184;

${ }^{56}$ Иванов В. Эстетика Эйзенштейна., с. 171;

${ }^{57}$ Иванов В. Эстетика Эйзенштейна., с. 177;

${ }^{58}$ Иванов В. Эстетика Эйзенштейна., с. 263;
}

${ }_{59}$ Паперный В. Культура Два. М., 1996., с. 51;

${ }^{60}$ Мотрошилова Н. С. Франк и Н. Бердяев о «новом варварстве» // Культура и форма. М., 2010., с. 173;

${ }^{61}$ Иванов В. Эстетика Эйзенштейна., с. 308 
6. Деррида Ж. О грамматологии. М., 2000;

7. Деррида Ж. Фрейд и сцена письма // Французская семиотика: От структурализма к постструктурализму. М., 2000;

8. Иванов Вяч. Очерки по истории семиотики в СССР. М., 1976;

9. Иванов Вяч. Очерки по предыстории истории семиотики// Иванов Вяч. Избранные труды по семиотике и истории культуры., т.1. Знаковые системы. Кино. Поэтика., М., Языки русской культуры. M., 1998;

10. Иванов Вяч. Эстетика Эйзенштейна //Иванов Вч. Избранные труды по семиотике и истории культуры., т. 1.. М., 1998;

11. Иванов Вяч. Язык кино // Иностранная литература. 1967., № 6;

12. Иванов Вяч. О структуре знаков кино// Тезисы докладов ІУ Летней школы по вторичным моделирующим системам. Тарту. 1970;

13. Иванов Вяч. О структурном подходе к языку кино // Точные методы в исследованиях культуры и искусства. М., 1971;

14. Иванов Вяч. Из заметок о строении и функциях карнавального образа // Проблема поэтики и истории литературы. Сборник статей к 75-летию со дня рождения и 50-летию научно-педагогической деятельности М. М. Бахтина. Саранск. 1973;

15. Иванов Вяч. Значение идей М. М. Бахтина о знаке, высказывании и диалоге для современной семиотики // Труды по знаковым системам. УІ., Тарту., 1973;

16. Иванов Вяч. Функции и категории языка кино // Труды по знаковым системам. УІІ. Тарту., 1975;

17. Иванов Вяч. Доктор Фаустус (Основные проблемы теории искусства С. М. Эйзенштейна) // РоссияRussia., № 3., 1977;

18. Иванов Вяч. Достоевский и Эйзенштейн // Творческий процесс и художественное восприятие. Л., 1977 ;

19. Иванов Вяч. Эстетическая концепция звукозрительного контрапункта у Эйзенштейна // Взаимодействие и синтез искусств. Л., 1979;

20. Иванов Вяч. Фильм в фильме // Труды по знаковым системам. ХІУ., Тарту., 1981;

21. Иванов Вяч. Эйзенштейн и культуры Японии и Китая // Восток и Запад: Исследования. Переводы. публикации. М., 1988;

22. Иванов Вяч. Монтаж как принцип построения в культуре первой половины XX века // Монтаж: Литература. искусство. Театр. Кино. М., 1988;

23. Иванов Вяч. От структуры к архетипу // Киноведческие записки. !993., № 19;

24. Иванов Вяч. Функции и категории языка кино // Из работ московского семиотического круга., М., 1997;

25. История эстетики. Памятники мировой эстетической мысли в 5 т., т. 2. Эстетические учения ХУІІXVIII веков. М., 1964;

26. Кристева Ю. Избранные труды: Разрушение поэтики. М., 2004;

27. Лотман Ю. О семиотическом механизме культуры // Лотман Ю. Избранные статьи в 3-х т., т.3. Таллинн., 1993;

28. Лотман Ю. Проблема «обучения культуре» как ее типологическая характеристика // Труды по знаковым системам. Выпуск 5., Тарту., 1971;

29. Медведев П. Формальный метод в литературоведении. Л., 1928;

30. Мотрошилова Н. С. Франк и Н. Бердяев о «новом варварстве»// Культура и форма. М., 2010;

31. Паперный В. Культура Два. М., 1996;

32. Соколов В. Киноведение как наука. М., 2010;

33. Хансен-Леве О. Русский формализм. Методологическая реконструкция развития на основе принципа остранения. М., 2001;

34. Хренов Н. Эстетический ренессанс эпохи оттепели // Экспериментальное искусство. Влияние теории на художественное творчество. Под редакцией О. Личчиарделло, С. Ломбардо, В. Петрова. M., 2011;

35. Хренов Н. От технологии суггестивного воздействия к эстетике диалога // Между обществом и властью. массовые жанры от 20-х к 80-м годам XX века. М., 2002;

36. Хренов Н. Кино как реабилитация архетипической реальности //Киноведческие записки. 2006., № 79;

37. Хренов Н. История искусства в ракурсе циклической парадигмы // Теория художественной культуры. Выпуск 5., М., 2001; 
38. Хренов Н. Сергей Эйзенштейн: от технологии суггестивного воздействия к эстетике диалога // Киноведческие записки. 2000., №46;

39. Федотов Н. Судьба и грехи России. Избранные статьи по философии русской истории и культуры. т. 2., СПб., 1992;

40. Шпигельберг Г. Феноменологическое движение. М., 2002;

41. Эйзенштейн С. Избранные произведения в 6 т., т. 2., М., 1964;

42. Эйзенштейн С. Метод. т. 1. Grundproblem. М., 2002;

43. Эйзенштейн С. Метод. т. 2. Тайны мастеров. М., 2002;

44. Эйхенбаум Б. Теория «формального метода» // Эстетика и теория искусства XX века. Хрестоматия. Ответственные редакуторы Н. Хренов, А. Мигунов., М., 2007;

45. Якобсон Р. Новейшая русская поэзия. Набросок первый: Пордступы к Хлебникову // Якобсон Р. работы по поэтике. М., 1987;

46. Якобсон Р. Формальная школа и современное русское литературоведение. М., 2011;

47. Ямпольский М. Видимый мир. Очерки ранней кинофеноменологии. М., 1993;

48. Ямпольский М. Язык-тело-случай: Кинематограф и поиски смысла. М., 2004

49. В.В. Софронов Предложение боли. Семиотические и феноменологические аспекты анализа романа Марселя Пруста «В поисках утраченного времени». // Филология: научные исследования. $-2012 .-1 .-$ C. $5-18$.

\section{References (transliterated):}

1. Avtonomova N. Derrida i grammatologiya// Derrida Zh. O grammatologii. M., 2000;

2. Berdyaev N. Sud'ba Rossii. Opyty po psikhologii voiny i natsional'nosti. M., 1918;

3. Gegel' G.Estetika. t.1., M. 1968;

4. Derrida Zh. Struktura, znak i igra v diskurse gumanitarnykh nauk // Frantsuzskaya semiotika: Ot strukturalizma k poststrukturalizmu. M., 2000;

5. Derrida Zh. Teatr zhestokosti i zavershenie predstavleniya // Frantsuzskaya semiotika; Ot strukturalizma k poststrukturalizmu. M., 2000;

6. Derrida Zh. O grammatologii. M., 2000;

7. Derrida Zh. Freid i stsena pis'ma // Frantsuzskaya semiotika: Ot strukturalizma k poststrukturalizmu. M., 2000;

8. Ivanov Vyach. Ocherki po istorii semiotiki v SSSR. M., 1976;

9. Ivanov Vyach. Ocherki po predystorii istorii semiotiki// Ivanov Vyach. Izbrannye trudy po semiotike i istorii kul'tury., t.1. Znakovye sistemy. Kino. Poetika., M., Yazyki russkoi kul'tury. M., 1998;

10. Ivanov Vyach. Estetika Eizenshteina //Ivanov Vch. Izbrannye trudy po semiotike i istorii kul'tury., t. 1.. M., 1998;

11. Ivanov Vyach. Yazyk kino // Inostrannaya literatura. 1967., № 6;

12. Ivanov Vyach. O strukture znakov kino// Tezisy dokladov IU Letnei shkoly po vtorichnym modeliruyushchim sistemam. Tartu. 1970;

13. Ivanov Vyach. O strukturnom podkhode $\mathrm{k}$ yazyku kino // Tochnye metody $\mathrm{v}$ issledovaniyakh kul'tury i iskusstva. M., 1971;

14. Ivanov Vyach. Iz zametok o stroenii i funktsiyakh karnaval'nogo obraza // Problema poetiki i istorii literatury. Sbornik statei k 75-letiyu so dnya rozhdeniya i 50-letiyu nauchno-pedagogicheskoi deyatel'nosti M. M. Bakhtina. Saransk. 1973;

15. Ivanov Vyach. Znachenie idei M. M. Bakhtina o znake, vyskazyvanii i dialoge dlya sovremennoi semiotiki // Trudy po znakovym sistemam. UI., Tartu., 1973;

16. Ivanov Vyach. Funktsii i kategorii yazyka kino // Trudy po znakovym sistemam. UII. Tartu., 1975;

17. Ivanov Vyach. Doktor Faustus (Osnovnye problemy teorii iskusstva S. M. Eizenshteina) // RossiyaRussia., № 3., 1977;

18. Ivanov Vyach. Dostoevskii i Eizenshtein // Tvorcheskii protsess i khudozhestvennoe vospriyatie. L., 1977 ;

19. Ivanov Vyach. Esteticheskaya kontseptsiya zvukozritel'nogo kontrapunkta u Eizenshteina // Vzaimodeistvie i sintez iskusstv. L., 1979;

20. Ivanov Vyach. Fil'm v fil'me // Trudy po znakovym sistemam. KhIU., Tartu., 1981; 
21. Ivanov Vyach. Eizenshtein i kul'tury Yaponii i Kitaya // Vostok i Zapad: Issledovaniya. Perevody. publikatsii. M., 1988;

22. Ivanov Vyach. Montazh kak printsip postroeniya v kul'ture pervoi poloviny KhKh veka // Montazh: Literatura. iskusstvo. Teatr. Kino. M., 1988;

23. Ivanov Vyach. Ot struktury k arkhetipu // Kinovedcheskie zapiski. !993., № 19;

24. Ivanov Vyach. Funktsii i kategorii yazyka kino // Iz rabot moskovskogo semioticheskogo kruga., M., 1997;

25. Istoriya estetiki. Pamyatniki mirovoi esteticheskoi mysli v 5 t., t. 2. Esteticheskie ucheniya KhUII-KhUIII vekov. M., 1964;

26. Kristeva Yu. Izbrannye trudy: Razrushenie poetiki. M., 2004;

27. Lotman Yu. O semioticheskom mekhanizme kul'tury // Lotman Yu. Izbrannye stat'i v 3-kh t., t.3. Tallinn., 1993;

28. Lotman Yu. Problema "obucheniya kul'ture" kak ee tipologicheskaya kharakteristika // Trudy po znakovym sistemam. Vypusk 5., Tartu., 1971;

29. Medvedev P. Formal'nyi metod v literaturovedenii. L., 1928;

30. Motroshilova N. S. Frank i N. Berdyaev o "novom varvarstve"// Kul'tura i forma. M., 2010;

31. Papernyi V.Kul'tura Dva. M., 1996;

32. Sokolov V. Kinovedenie kak nauka. M., 2010;

33. Khansen-Leve O. Russkii formalizm. Metodologicheskaya rekonstruktsiya razvitiya na osnove printsipa ostraneniya. M., 2001;

34. Khrenov N. Esteticheskii renessans epokhi ottepeli // Eksperimental'noe iskusstvo. Vliyanie teorii na khudozhestvennoe tvorchestvo. Pod redaktsiei O. Lichchiardello, S. Lombardo, V. Petrova. M., 2011;

35. Khrenov N. Ot tekhnologii suggestivnogo vozdeistviya k estetike dialoga // Mezhdu obshchestvom i vlast'yu. massovye zhanry ot 20-kh k 80-m godam KhKh veka. M., 2002;

36. Khrenov N. Kino kak reabilitatsiya arkhetipicheskoi real'nosti //Kinovedcheskie zapiski. 2006., № 79;

37. Khrenov N. Istoriya iskusstva $\mathrm{v}$ rakurse tsiklicheskoi paradigmy // Teoriya khudozhestvennoi kul'tury. Vypusk 5., M., 2001;

38. Khrenov N. Sergei Eizenshtein: ot tekhnologii suggestivnogo vozdeistviya k estetike dialoga // Kinovedcheskie zapiski. 2000., №46;

39. Fedotov N. Sud'ba i grekhi Rossii. Izbrannye stat'i po filosofii russkoi istorii i kul'tury. t. 2., SPb., 1992;

40. Shpigel'berg G. Fenomenologicheskoe dvizhenie. M., 2002;

41. Eizenshtein S. Izbrannye proizvedeniya v 6 t., t. 2., M., 1964;

42. Eizenshtein S. Metod. t. 1. Grundproblem. M., 2002;

43. Eizenshtein S. Metod. t. 2. Tainy masterov. M., 2002;

44. Eikhenbaum B. Teoriya "formal'nogo metoda" // Estetika i teoriya iskusstva KhKh veka. Khrestomatiya. Otvetstvennye redakutory N. Khrenov, A. Migunov., M., 2007;

45. Yakobson R. Noveishaya russkaya poeziya. Nabrosok pervyi: Pordstupy k Khlebnikovu // Yakobson R. raboty po poetike. M., 1987;

46. Yakobson R. Formal'naya shkola i sovremennoe russkoe literaturovedenie. M., 2011;

47. Yampol'skii M. Vidimyi mir. Ocherki rannei kinofenomenologii. M., 1993;

48. Yampol'skii M. Yazyk-telo-sluchai: Kinematograf i poiski smysla. M., 2004

49. V.V. Sofronov Predlozhenie boli. Semioticheskie i fenomenologicheskie aspekty analiza romana Marselya Prusta «V poiskakh utrachennogo vremeni». // Filologiya: nauchnye issledovaniya. -2012. - 1. - C. 5 - 18. 